$1-1-2006$

\title{
Primary instability paradox: The ethics of media coverage in presidential nominations
}

Andrew R. Cline

Missouri State University

Follow this and additional works at: https://bearworks.missouristate.edu/articles-coal

\section{Recommended Citation}

Cline, Andrew R. "Primary Instability Paradox: The Ethics of Media Coverage in Presidential Nominations." In The Forum, vol. 3, no. 4. De Gruyter, 2006.

This article or document was made available through BearWorks, the institutional repository of Missouri State University. The work contained in it may be protected by copyright and require permission of the copyright holder for reuse or redistribution.

For more information, please contact BearWorks@library.missouristate.edu. 


\title{
Primary Instability Paradox: The Ethics of Media Coverage in Presidential Nominations
}

\author{
Andrew R. Cline
}

\begin{abstract}
This essay explores the ethics of how the press covers presidential nomination campaigns. It considers the implications of a predictive model that demonstrates how the nomination process limits voters' choices. Nominees may be predicted with a high degree of success before voting begins. Horse-race press coverage of the pre-primary period dramatically characterizes the process as unstable and up for grabs. By doing so, the press paradoxically contributes to the stability and, therefore, is complicit in limiting voter choice. The essay argues for telling the story of the impact of policy and governance on citizens' lives.
\end{abstract}

KEYWORDS: journalism, media, campaigns

Author Notes: Andrew R. Cline is an assistant professor of journalism at Missouri State University. He teaches courses in print journalism and media ethics. 
In this essay I explore the ethical implications for journalists of the Mayer (1996, 2003) predictive model of presidential primary campaigns. I am specifically interested in press coverage of the nomination process from the candidates' announcements to the Iowa caucuses. I accept the argument by Barger and Barney (2004, p. 191) that the press has an obligation to "enable citizens, through timely access to information, to accumulate the power necessary...to control their own destinies." I also accept that journalists aspire to act ethically in regard to the integrity of their product and the public they serve (Kovach \& Rosenstiel, 2001; Merrill, 1997). Recent scholarship on the effects of party election reforms in the 1970s demonstrates that the primary election process has become frontloaded (Mayer, 2004). Frontloading occurs as states move primary dates forward in an effort to gain more media attention and political influence in the nomination. Frontloading has stabilized the nomination process by making it a "stacked deck" in favor of a limited set of candidates before any votes are cast (Steger, 2003). Since the reforms fully took effect in 1980, the winner of the "invisible primary," as determined by polls prior to voting, has eventually won the nomination most of the time (Mayer, 1996, 2003; Gurian \& Haynes, 2003). The press, however, covers the nomination process as an unstable event by creating an illusion of political drama in which almost any candidate may rise from the pack to win the nomination or the frontrunner may stumble on political mistakes and lose the nomination (Gurian \& Haynes, 2003). This illusion of drama hides from citizens the fact that the process is stable and, therefore, limits voters' choiceshardly helping them to "control their own destinies." By characterizing the process as unstable, I contend that the press contributes to its stability; thus, the press is complicit in limiting voter choice, a phenomenon I call the primary instability paradox.

I will argue in this essay that the press ought to change the narrative structure of pre-primary campaign coverage from a horse race focused on winning polls and cash to the story of the effect of candidates' policies on citizens' lives.

Mayer's predictive model demonstrates, with a high degree of predictive success, that the nomination process effectively ends before the Iowa caucuses because a choice will have been made. The model has correctly predicted nine of 11 contested primaries for Republicans and Democrats since 1980. Anomalies include Gary Hart in 1988 and Howard Dean in 2004. The press plays a perhaps troubling role in causing the success of this predictive model.

The model has two independent variables (see Table 1). First, the candidate must lead in the last Gallup poll before the Iowa caucuses. Mayer confined his research to data gathered by Gallup because it "has a very good track record for doing careful, unbiased survey work, and . . . because Gallup is the only organization that has asked questions on this topic continuously over the last two decades" (2003, p. 153). Second, the candidate must be the most effective 
fundraiser before the Iowa caucuses. Further, Mayer's data demonstrate that winning candidates have usually led in polls for more than a year before the Iowa caucuses. Mayer draws these conclusions from his model: (1) the current nomination/primary system favors frontrunners; (2) momentum is an overrated factor in the process; (3) the frontrunner often stumbles, but these incidents are rarely fatal; (4) the longer we live with this system, the more we learn about it, and this works to the advantage of frontrunners; (5) money is important, but it is not "the whole ball game."

Table 1. Regression Equations for Predicting Primary Vote Shares

\begin{tabular}{lccc}
\hline & $1980-1992$ & $1980-1996$ & $1980-2000$ \\
\hline Regression Coefficients & & & \\
$\quad$ National poll standings & $.94(.14)$ & $.99(.13)$ & $1.05(.11)$ \\
Total funds raised & $.02(.08)$ & $.00(.07)$ & $-.02(.06)$ \\
Constant & $1.31(3.37)$ & $1.57(3.13)$ & $1.72(2.66)$ \\
$\mathrm{R}^{2}$ & .70 & .72 & .77 \\
Adjusted $\mathrm{R}^{2}$ & .69 & .70 & .77 \\
$\mathrm{SEE}$ & 11.93 & 11.50 & 10.91 \\
$\mathrm{~N}$ & 38 & 44 & 52 \\
\hline
\end{tabular}

Source: Mayer, W. (2003). "Forecasting Presidential Nominations or, My Model Worked Just Fine, Thank You." PS: Politics \& Political Science 35: 153-57.

The candidate's public ethos and past political performance (as opposed to governance) have already created the argument, the message, and the image. The combination of these becomes the candidate's master narrative. As long as the frontrunner avoids disaster, he or she simply must maintain a positive master narrative. Mayer says:

presidential nomination races will be decided more and more on the basis of such fundamental factors as popularity and money-resources that frontrunners, almost by definition, will have in greater supply than their competitors. (2003, p. 156)

Popularity and fundraising are two crucial elements in the ubiquitous horse-race style of political coverage. Polls taken by the news media help the press compare popularity. Fundraising figures offer the press an empirical measure of political legitimacy among contributors. Mayer's model says nothing about how the press covers political campaigns. But my interpretation of his data shows how press coverage in the months prior to the primary election season is critical for a candidate's success in winning the nomination for either of the two major political 
parties, even though many Americans do not begin paying close attention to the campaign until the general election (Gurian \& Haynes, 2003).

One wonders what information citizens are using to make up their minds as reflected in the polls taken during the year preceding the primaries. Is it the kind of information promised in the codes of ethics of the Society of Professional Journalists (SPJ), the American Society of Newspaper Editors (ASNE), and the Associated Press Managing Editors (APME)? As journalists themselves complain (Robertson, 2000), very little press coverage of a political campaign during the pre-election year focuses on the creation, implementation, and critique of policy (Hanson, 2003). At this point, the campaign is a popularity contest based on name recognition and whatever political or personal image already exists in the public mind. Mayer's model demonstrates that the contest ends long before voters hear much about policy.

Journalism operates with a set of informational biases (Bennett, 2001) that determine what it is that journalists understand or "see" in a news situation and how they may relay what they understand to citizens. These informational biases may also be thought of as frames or structural biases. Narrative is among thesethe structuring of news situations into stories using all of the elements of literary narrative, especially including a central conflict between protagonists and antagonists. The narrative bias is the tendency of the press to structure issues in terms of stories - human drama - for the purpose of creating a coherent and causal sense of events. Further, this bias tends to promote the creation of master narratives, which are set story lines that create a basic understanding of how and why individual candidates act as they do in political situations. Conflict among politicians, especially regarding campaign tactics thought to affect standing in the polls and fundraising, is one of the definitions of news about politics.

The primary season is a highly stable political event because the outcome may be predicted with a high degree of success prior to voting (Mayer, 1996, 2003, 2004; Adkins \& Dowdle, 2001). Yet the press covers the pre-primary and primary seasons as volatile, or unstable, political events (Gurian \& Hayes, 2003). The master narrative of the nomination process dictates that these races are up for grabs among many political actors. The data, however, do not support this view. Mayer's data suggest that the most important period of the campaign is the summer and fall before the Iowa caucuses. During this period, a candidate must create a presidential image and a winning story. That image and story must be adopted by the press as the master narrative for that candidate. But, like all great fiction, the protagonist may not attain the resolution of the story too easily nor the climax too soon. Hence, the press looks for drama, and often creates drama (the illusion of instability), in an otherwise undramatic and stable system. The drama they seek is human: candidate versus candidate. This search for human drama 
dictates that policy analysis is boring and unworthy of serious scrutiny unless it somehow collides with the human drama of political maneuvering.

The structure of the nomination process and its mediation by the press creates a situation in which the press helps choose who will win the nomination. Mayer's data suggest that voters in the primaries merely rubber stamp the choice. The process works this way: (1) during the course of normal political reporting following an election cycle, the press begins speculating who might run four years hence and reporting on those who take active steps toward running; (2) as politicians announce their candidacies, the press evaluates their viability (by deciding who to cover and how much coverage to offer) and assigns motives to their actions (Gans, 2003)—most often based on name recognition, current political status, and fundraising ability; (3) master narratives created by the candidates and the press lock candidates into set roles with set motives; (4) horserace style articles inform voters about these roles and motives and about which candidates are "winning" or "leading" in comparison to other candidates, while the polls confirm the reporting.

I contend that the journalist's role in this process fails the ethical standards journalism has set for itself based on democratic values in the codes of ethics of three prominent professional organizations.

The press should not portray a stable process as unstable merely because such framing does not conform to the facts. But a narrative bias blinds the press to the ethical issue: the stability of the process, which we experience as a predictable, frontloaded process, limits voters' choices.

In a plea to journalists to change the way they cover politics in the preprimary phase of the nomination process, Hanson (2003) argued that journalists should frontload their reporting and avoid typical horse-race coverage in favor of covering candidates' policies and characters:

One might think the audience isn't interested yet, that war and terrorism will all but monopolize this year's news. In fact, voters probably would be very interested to learn that the system is cheapening their franchise. Compelling news reports that put this message across just might goad them to demand comprehensive candidate news while their voices and financial contributions still matter. (n. pag.)

Hansen's suggestion that the press cover the candidates' policies and characters is a good one. But much of the hand-wringing that appears in the pages of the Columbia Journalism Review and American Journalism Review at the end of election cycles merely hopes for procedural solutions. Instead, journalists should take a critical look at how the structure of journalistic ways of knowing prompt them to see certain types of stories as news and others as not news. Fact- 
checking the candidates' advertisements and speeches was the panacea in 2004. Both journals ran articles in 2004 arguing that campaign coverage should focus more on fact-checking candidates' messages. Robertson (2004) argues that while news organizations did fact-check the two nominees, this practice should have begun sooner in the process. Keefer (2004) struggled with the concept of journalistic objectivity and how journalists can fact-check-including identifying outright lies - without seeming biased. Such fact-checking is certainly a good idea and finds safe harbor in Jamieson \& Waldman's (2003) concept of the press as a custodian of facts and Kovach \& Rosenstiel's discipline of verification. But for a press caught up in the frenzy of the race metaphor, even this common-sense suggestion seems impossible to accomplish. An editorial in the September/October 2004 issue of the Columbia Journalism Review lamented the hectic pace of campaign coverage, 24-hour deadlines, and "a never-ending torrent of digital spin...This system encourages busy reporters - even good ones - to lean on someone else's version of the truth instead of assembling a more complete version of their own" (pg. 8). But the campaign is hectic for journalists precisely because they view it through the metaphor of a race. And this metaphor makes it difficult for them to see that they could tell a different story with different conflicts and different protagonists - a story that would be far more politically useful to citizens.

I have discussed in terms of ethics what journalists ought not do. While the literature of press and politics is full of condemnations of horse-race coverage, the press seems incapable of re-thinking this practice. Hence, I make the argument in terms of ethics because journalists view themselves as having high ethical standards and understand their practice to be an integral part of the civic life of a democracy. No credible journalist wants to make civic life more difficult for voters.

Now, what might journalists do instead? My own suggestion for covering the pre-primary period proceeds from the assumption that ethical standards associated with a social responsibility theory of journalism, as asserted in the codes of ethics, currently represent the ethical ideals of the profession of journalism in $21^{\text {st }}$ century America. Since the report of the Hutchins Commission on Freedom of the Press in 1947, the profession of journalism has been steadily accepting a social responsibility theory of journalism. Recent expressions of this theory include Kovach \& Rosenstiel's (2001) The Elements of Journalism and expressions of social responsibility in the codes of ethics of SPJ, ASNE, and APME. Like the Hutchins Commission report before them, these codes accept that providing the information necessary to help make civic life work is an important role of the press. None of the codes defines the quality of this information, but Kovach \& Rosenstiel (2001) offer a specific list of nine practices that define what citizens need from the press and why the press should provide it. The codes are less 
specific, but surely align with Kovach \& Rosenstiel. For example, the preamble to the SPJ code asserts that "public enlightenment is the forerunner of justice and the foundation of democracy," and the "duty of the journalist is to further those ends by seeking truth and providing a fair and comprehensive account of events and issues." The ASNE code states it this way under the heading "responsibility": "The primary purpose of gathering and distributing news and opinion is to serve the general welfare by informing the people and enabling them to make judgments on the issues of the time." The APME believes that a newspaper has a "responsibility as surrogate of its readers to be a vigilant watchdog of their legitimate public interests." Each of these expressions accepts that the press has a social responsibility to help citizens make public life work by providing them information about public affairs - information, I would argue, that must have the political utility that horse-race coverage lacks.

This ethic of providing such information to the public fits journalism's operating theory of democracy, which asserts the journalist's role is to inform citizens about civic affairs, and the citizens' role is to become informed by consuming journalistic messages. Citizens are assumed to be informed if journalism provides this information. Further, citizens armed with such information are assumed more likely to participate in civic affairs, and this will make America more democratic (Gans, 2003). Coverage that focuses on who is ahead in the polls or fundraising, that focuses on the drama of competing policies versus their political utility, fails to provide citizens with information for making rational political choices based on policy and governance - the very things that affect their lives. Further, such coverage suggests that the primary election process is less stable than it actually is and that a greater number of candidates have a chance to win than actually do. In other words, the press offers a narrative of primary elections that does not conform to the data. Richard Morin, in a column for the Washington Post (2003), provides an interesting example of how an individual journalist can fail this model. Morin interviewed Mayer about his predictive model in October of 2003, more than two months before primary voting would begin in the 2004 presidential election. He began the column this way:

The media love to portray the presidential primary season as a wild and unpredictable ride, during which virtually anyone can win the nomination through the steamrolling power of the "Big Mo" and hapless front-runners stand ready to be toppled by a stumble on the campaign trail. (p. B5)

Mayer's research demonstrates that this is a false narrative of primary campaigns, which Morin readily accepts. The balance of the column breezes through Mayer's research showing how it challenges press assumptions about 
political momentum and fundraising. But at no point does Morin ask: if Mayer is right, what does this say about the way the press covers presidential campaigns? What does this say about how I should do my job? What are the ethical considerations of covering a pre-primary campaign using a master narrative that fails to conform to what is really happening in the world? Am I really providing the kind of information to citizens that helps make civic life work? What's a more important story?

Predictive models may certainly fail, as Mayer's did in 2004. Vermont Governor Howard Dean led the last Gallup poll published on 13 January 2004 with 26 percent. Senator John Kerry polled 9 percent (Moore, 2004). Mayer argued in The Forum in late 2003 that Dean's position in the race in regards to the predictive model was not strong for two reasons: (1) "[i]n seven of ten contested races since 1980, the eventual nominee had opened up a sizeable lead . . . by one month after the preceding midterm election"-more than a year before primaries; and (2) while Dean had much early success in fundraising, the model demonstrates that fundraising is of secondary importance to position in the polls. Still, under the current set of nomination rules and the frontloading it encourages, the master narrative of an unstable nomination campaign simply is not true most of the time.

Certainly, horse-race coverage is important to a certain extent. How well the candidates fare in the polls and in fundraising is certainly news and must be covered. To make such coverage the primary narrative, however, fails the ethical standards journalists set for themselves by delivering to the public articles low in political utility. The irony for me of the primary instability paradox is that there may be almost nothing the press can do not to play a troubling role by contributing to the stability of the process. To make journalism is to make editorial choices that will have some effect on the way the public views the candidates. If that is so, then it seems to me that the press ought to focus its attention on those issues with a higher degree of political utility. Fact-checking advertisements and speeches and covering issues of character and policy are certainly steps in the right direction. But I argue the press must also change the narrative. I think the press needs to tell a different story during the pre-primary campaign - the story of how policy and governance affect people. In such narratives, the people, not the candidates, are the primary protagonists.

Nearly every candidate for president has a record of policy and governance. Stories told from the candidate's point of view tend to remain abstract regarding how policy worked or failed to work. The drama of the narrative is created by pitting the policy and governance choices of one candidate against another. What happens if the press decides, in addition to such coverage, to spend more time and space telling the story of citizens' encounters with policy and governance? The drama in such stories would necessarily demand evaluations of effectiveness. 
Who was affected? How? Did it work? If so, why and how? Who benefited? Who did not? Are the people better off? The press does cover such stories during political campaigns. But such stories are merely occasional features added as spice to a stew of campaign contention, fundraising, and poll numbers. But I contend that such narratives have a higher degree of political utility because they could tell citizens stories of political effectiveness, thus potentially allowing them to make a choice based on an assessment of their interests and values.

\section{References}

Adkins, R. \& Dowdle, A. J. 2001. "Is the Exhibition Season Becoming More Important to Forecasting Presidential Nominations? American Politics Research 29: 283-288.

ASNE Statement of Principles. 2002. American Society of Newspaper Editors. $<\mathrm{http}$ ://www.asne.org/kiosk/archive/principl.htm $>$

Barger, W. \& Barney R. D. 2004. "Media-Citizen Reciprocity as a Moral Mandate." Journal of Mass Media Ethics 19: 191-206.

Bennett, L. W. 2001. News: The Politics of Illusion. New York: Addison.

Cook, T. E. 1998. Governing with the News. Chicago: University of Chicago Press.

Ethics Code: Associated Press Managing Editors. 1994. American Society of Newspaper Editors. < http://www.asne.org/index.cfm?ID=388>

Gans, H. 2003. Democracy and the News. New York: Oxford University Press.

Gurian, P. \& Haynes A. A. 2003. "Presidential Nomination Campaigns." PS: Politics \& Political Science 36: 175-80.

Hanson, C. 2003. "The Invisible Primary." Columbia Journalism Review. $<$ http://www.cjr.org/issues/2003/2/voices-hanson.asp $>$

Jamieson, K. \& Waldman, P. (2003) The Press Effect: Politicians, Journalists, and the Stories That Shape the Political World. New York: Oxford University Press.

Keefer, B. 2004. "Tsunami." Columbia Journalism Review. p. 18. Retrieved Oct. 3, 2005 from the LexisNexis Academic database.

Kovach, B. \& Rosenstiel, T. 2001. The Elements of Journalism. New York: Crown.

Mayer, W. G. 2004. The Front-Loading Problem in Presidential Nominations. Washington D.C.: Brookings Institution.

. 2003. "Forecasting Presidential Nominations or, My Model Worked Just Fine, Thank You." PS: Politics \& Political Science 36: 153-57. 
. 1996. "Forecasting Presidential Nominations." In In Pursuit of the White House: How We Choose our Presidential Nominees, ed. Mayer, E. G. Chatham, NJ: Chatham House, 44-77.

. 2003. "Handicapping the 2004 Nomination Race: An Early Fall

Prospectus. The Forum, Vol. 1: No. 4, Article 1.

$<$

Merrill, J. C. 1997. Journalism Ethics: Philosophical Foundations for News Media. New York: Bedford/St. Martin's.

Moore, D. W. 2004. "Nationally: Two-Candidate Race for Democratic

Nomination?" The Gallup Organization. 13 Jan.

$<$ http:/www.gallup.com/poll/content/ print.aspx?ci $=10186>$

Morin, R. 2003. “A Big No to Big Mo.” Washington Post. 26 Oct., B5.

Parenti, M. 1986. Inventing Reality: The Politics of the Mass Media. New York: St. Martin's.

Robertson, L. \& Papai L. 2000. Campaign Reform. American Journalism Review. Sept. $<$ http://www.ajr.org/article.asp?id=686>

Robertson, L. 2004. "Campaign Trail Veterans for Truth." American Journalism Review. Pg. 38. Retrieved Oct. 3, 2005 from the LexisNexis Academic database.

Smolkin, R. 2003. "The Crowded Bus.” American Journalism Review. April. $<$ http://www.ajr.org/Article.asp?id=2894>

SPJ Code of Ethics. 1996. Society of Professional Journalists.

$<$ http://spj.org/ethics.asp $>$

Steger, W. P. 2000. "Do Primary Voters Draw from a Stacked Deck? Presidential Nominations in an Era of Candidate-Centered Campaigns." Presidential Studies Quarterly 30: 727-53.

"The boys on the broken bus." 2004. Columbia Journalism Review. p. 8. Retrieved Oct. 3, 2005 from the LexisNexis Academic database. 